\title{
Atomvåben fortsat en reel trussel
}

Af John Kierulf

Siden bombningen af Hiroshima og Nagasaki $i$ august for 70 år siden har verden været forskånet for anvendelse af atomvåben i krig. Antallet af atomvåben er blevet reduceret kraftigt siden den kolde krig, men der er ringe udsigt til yderligere væsentlige reduktioner af atomvåben i den nærmest overskuelige fremtid. Atomvåben er blevet spredt til flere lande end de oprindelige fem atomvåbenstater, $\mathrm{og}$ risikoen for spredning af atomvåben til endnu flere lande er voksende. Der er behov for flere tiltag med henblik på at fremme nedrustning af atomvåben $\mathrm{og}$ forhindre yderligere spredning af atomvåbenteknologi og -materialer. Bestræbelserne på at opnå international enighed om en folkeretligt bindende aftale om forbud mod atomvåben bør intensiveres, og Danmark bør aktivt medvirke til at søge forhandlinger indledt om en konvention om forbud mod atomvåben.

I august for 70 år siden blev atomvåben anvendt for første - og hidtil eneste - gang i krig, da amerikanske bombefly nedkastede to atombomber over Hiroshima og Nagasaki. Den rædselsful- de virkning af atomeksplosionerne var, at ca. 120.000 mennesker - hovedsagelig civile - blev dræbt øjeblikkeligt som følge af bombernes enorme varmeudvikling og trykbølge. Titusinder omkom senere af radioaktiv bestråling, og kræftfremkaldende genmodifikationer som følge af strålingen er blevet overført fra overlevende bombeofre til deres efterkommere og vil fortsat forekomme i generationer fremover. Siden de to atombombeeksplosioner over Japan i 1945 har atomvåben ikke været anvendt i krig, men brugt som politisk og militært afskrækkelsesmiddel - især under den kolde krig.

I årene kort efter afslutningen på Anden Verdenskrig advarede flere af de atomfysikere, hvis forskning havde resulteret i udviklingen af de første amerikanske atombomber - bl.a. professor Niels Bohr - imod faren for spredning af atomvåbenteknologi. Videnskabsfolkene foreslog etablering af international kontrol med udnyttelsen af kerneenergien alene til fredelige formål. Disse advarsler viste sig desværre at være forgæves, selvom der lige siden 1945 har været gjort talrige forsøg på at afskaffe eller i det mindste begrænse udbredelsen af atomvåben.

John Kierulf er fhv. ministerråd i Udenrigsministeriet. I 2012-2013 var han seniorgæsteforsker ved Dansk Institut for Internationale Studier. Han er forfatter til bogen Nedrustning - i et folkeretligt perspektiv (Djøf Forlag, 2014]. 
Med oprettelsen i 1957 af Det Internationale Atomenergiagentur - IAEA - er der dog blevet etableret kontrol med den fredelige udnyttelse af kerneenergi på atomkraftværker.

Hvordan er det så gået med hensyn til at reducere antallet af atomvåben og begrænse spredningen af atomvåben til flere lande?

\section{Reduktion af atomvåben}

Nedrustningen af atomvåben har gjort betydelige fremskridt siden den kolde krig: Det totale antal atomvåben i verden er blevet reduceret fra 65.000 i 1985 til ca. $16.000 \mathrm{i}$ dag. Langt det største antal atomvåben (ca. 95 procent) findes fortsat i USA og Rusland, hvis arsenaler tilsammen indeholder over 15.000 atomvåben - $7.300 \mathrm{i}$ USA og 8.000 i Rusland, hvoraf henholdsvis 2.100 og 1.600 atomsprænghoveder er deployeret på missiler eller luftbaser med operationelle styrker. De fleste deployerede atomvåben er fortsat i højt beredskab, dvs. klar til affyring med få minutters varsel.

USA og det tidligere Sovjetunionen/ Rusland indgik i årene 1972-2002 en række bilaterale aftaler om begrænsninger og reduktioner af antallet af deres strategiske atomvåben (SALT I og II, START I og II og SORT). Den seneste traktat mellem USA og Rusland (New START) er fra 2010. Ifølge denne traktat skal hvert land inden den 5. februar 2018 have reduceret antallet af sine operativt deployerede, strategiske atomsprænghoveder til højst 1.550 .

Men det sikkerhedspolitiske klima mellem USA og Rusland er i de seneste par år blevet stærkt forværret på grund af Ukraine-konflikten. Der er derfor ringe udsigter til, at de to lande i den nærmest overskuelige fremtid vil tage nye initiativer til at foretage væsentlige reduktioner af deres beholdninger af atomvåben.

\section{Spredning af atomvåben}

Det er gået mindre godt med hensyn til ikke-spredningen af atomvåben. Ud over de fem oprindelige atomvåbenstater, hvis besiddelse af atomvåben blev legitimeret $\mathrm{i}$ Ikke-spredningstraktaten (NPT) fra 1968 - USA, Rusland, Storbritannien, Frankrig og Kina - har Nordkorea, Israel, Indien og Pakistan anskaffet sig atomvåben. Israel har dog aldrig anerkendt at have atomvåben. De tre sidstnæunte lande er ikke deltagere i Ikke-spredningstraktaten. Nordkorea opsagde sin deltagelse i traktaten i 2003.

Fremtrædende tidligere politiske koldkrigere og militære chefer har bl.a. i 'Nuclear Security Project' udtalt, at verden er nået til et afgørende vendepunkt med hensyn til atomvåben: Enten reduceres og i sidste ende afskaffes alle atomvåben, eller også kan atomvåben med stor sandsynlighed forventes spredt til endnu flere lande - og hvad der er endnu værre - til terrororganisationer, der ikke lader sig skræmme af atomvåbenstaternes nukleare afskrækkelsesstrategier.

Den netop indgåede aftale med Iran om skærpet international kontrol med det iranske atomprogram (Joint Comprehensive Plan of Action - JCPOA) er et væsentligt, positivt skridt i retning af at begrænse spredningen af atomvåben til flere lande, bl.a. i Mellemøsten. Men Nordkoreas netop genstartede atomprogram og planlagte afprøvning af langtrækkende missiler giver anledning til bekymring for yderligere spredning af teknologi og materialer til brug for fremstilling af atomvåben.

Risikoen for at atomvåben vil blive spredt til flere lande eller ikke-statslige ak- 
tører (bl.a. terrororganisationer) er reel og udgør en voksende trussel mod det internationale samfund. Især risikoen for, at atomvåben eller atomvåbenteknologi og -materialer kan falde i hænderne på terrororganisationer må tages alvorligt og søges forhindret gennem yderligere internationale tiltag.

Mindst fem terrororganisationer, inklusive al Qaeda og Islamisk Stat, har vist interesse for at anskaffe sig atomvåben eller nukleare materialer. Siden 1993 har IAEA registreret omkring 2.500 tilfælde af tyveri, mangel på kontrol, uautoriseret besiddelse og ulovlig handel med nukleare materialer. Der har været mindst 18 tilfælde af tyveri eller bortkomst af nukleare materialer, som kunne anvendes til såkaldte dirty bombs, dvs. bomber, der spreder radioaktivt materiale ved hjælp af konventionelle sprængstoffer.

Der er derfor et akut behov for at skærpe kontrollen med og forøge sikkerheden omkring nukleare materialer (uran og plutonium) mod bl.a. tyveri. Et nyt initiativ hertil er blevet taget i form af et udkast til en international konvention om nuklear sikkerhed, som blev fremlagt $i$ Washington i marts i år. Én af forfatterne til konventionsudkastet er den tidligere danske ambassadør i Wien ved bl.a. IAEA, John Bernhard. Konventionsudkastet indeholder et sæt bindende standarder for de nationale nukleare sikkerhedsregimer, som bygger på IAEA's sikkerhedsregime.

I konventionsudkastet defineres nuklear sikkerhed som "forhindring og opdagelse af og handling over for tyveri, sabotage, uautoriseret adgang, ulovlig overførsel eller andre ondsindede handlinger, som omfatter nukleare eller andre radioaktive materialer eller tilhørende faciliteter og udstyr". Håbet er, at udkastet inden for de næste år kan danne grundlag for forhand- linger på mellemstatsligt plan om en sådan konvention.

Den reelle trussel fra atomvåbnene, som fortsat udgør den største, akutte fare for hele menneskeheden, bør tages mere alvorligt af politikerne, som bør tage seriøse skridt til at søge atomvåbnene afskaffet. Vi lever alle i konstant fare for, at atomvåben vil blive anvendt af såkaldte slyngelstater eller af terrororganisationer eller som følge af misforståelser, fejlkalkulationer, menneskelige fejl, teknologiske svigt eller ulykker - med katastrofale konsekvenser af hidtil ukendt omfang til følge.

\section{Konvention om forbud?}

Et stort flertal af verdens lande mener ikke, at de fem oprindelige atomvåbenstater har opfyldt deres forpligtelse i henhold til Ikke-spredningstraktaten til i god tro at forhandle om nedrustning af deres atomvåben.

USA, Rusland, Storbritannien, Frankrig og Kina har bl.a. blokeret for, at der indledes forhandlinger om atomnedrustning $\mathrm{i}$ Nedrustningskonferencen i Genève. I stedet for at forhandle om atomnedrustning foretager alle de fem atomvåbenstater moderniseringer og udvikler nye atomvåben. Alene USA planlægger at anvende 30 milliarder dollar på modernisering og nyudvikling af amerikanske atomvåben i løbet af de kommende ti år. Moderniseringen omfatter de 180 taktiske atombomber, som USA fortsat har placeret i fem europæiske lande - Tyskland, Nederlandene, Belgien, Italien og Tyrkiet. Rusland kræver de amerikanske atomvåben i Europa fjernet, førend man fra russisk side er parat til at drøfte yderligere atomnedrustning.

Der har i årtier været gjort forsøg på at opnå enighed om vedtagelse af et folkeretligt bindende forbud mod anvendel- 
se af atomvåben. Allerede i 1961 vedtog FN's generalforsamling en resolution med titlen Erklæring om forbud mod anvendelse af nukleare og thermo-nukleare våben, hvori generalforsamlingen bl.a. erklærer, at

- anvendelsen af atomvåben er i modstrid med ånden, bogstavet og formålene med FN og er en direkte overtrædelse af FN-pagten,

- anvendelsen af atomvåben forårsager vilkårlig lidelse og ødelæggelse for menneskeheden og civilisationen, og er derved i modstrid med reglerne i folkeretten og menneskeretten,

- enhver stats anvendelse af atomvåben bør betragtes som en overtrædelse af
FN-pagten, i modstrid med menneskehedens love og som en forbrydelse mod menneskeheden og civilisationen.

Resolutionen blev vedtaget med 55 stemmer for, bl.a. Sovjetunionen, 20 imod, bl.a. de fire øvrige atomvåbenstater og 26 afståelser, bl.a. de nordiske lande. Ikke-atomvåbenstaterne kræver, at der indledes forhandlinger om en folkeretligt bindende aftale om forbud mod atomvåben $-\mathrm{i}$ lighed med konventionerne om forbud mod biologiske og kemiske våben af henholdsvis 1972 og 1993. Danmark bør aktivt medvirke til at søge forhandlinger indledt om en konvention om forbud mod atomvåben. 